\title{
Will Chinese System of Fiscal Decentralization Inhibit the Environmental Investment?
}

\author{
Dahua Kang \\ College of Economics, Jinan University, Guangzhou, China \\ Email: beyondkangdahua@163.com
}

Received 30 March 2016; accepted 17 April 2016; published 21 April 2016

Copyright () 2016 by author and Scientific Research Publishing Inc. This work is licensed under the Creative Commons Attribution International License (CC BY). http://creativecommons.org/licenses/by/4.0/ (c) (i) Open Access

\section{Abstract}

This paper mainly investigated the effect of Chinese system of fiscal decentralization on the environmental investment. Being different from the previous studies that believed fiscal decentralization would inhibit the environmental investment, this paper believed that the fiscal decentralization both had a substitution effect and an income effect on the environmental investment, there was a U-type relationship between the both. Thus, a fiscal system reform has to be done, and more than anything else, the transfer payment from the exchequer to the less developed areas needs to be enhanced to solve the environmental issue of the less developed areas.

\section{Keywords}

Fiscal Decentralization, Environmental Investment, U-Type Relationship

\section{Introduction}

The literatures studying the effect of fiscal decentralization on the environment treatment usually share a common issue, that is, no agreement has been reached as to the mechanism of action of the effect of fiscal decentralization on the environment treatment. Zhang Xinyi (2014) referred to this process of conduction as "black box", and tried to explain it from three perspectives which were structure of fiscal expenditure, central transfer payment intensity and choice of local industry policies [1]. This paper took the environmental investment as a variable being explained, from the perspective of investigating the effect of fiscal decentralization on the environmental investment, this paper investigated its effect on the environment treatment.

The environment treatment investment fund of a place was mainly originated from the governmental financial investment, enterprise investment, investment of environmental protective commonweal organization and so on, 
among which governmental financial investment played a leading role. It is thus clear that the fiscal decentralization system had a direct influence on the local environmental investment, the economic incentive and political incentive under the system of fiscal decentralization made the local government expenditure to be partial to the economical public goods (Fu Yong, 2010) [2], most of the scholars also believed that fiscal decentralization had a negative influence on the environmental quality (Yang Ruilong, 2007) [3].

Besides, there are a few scholars believing that the regions having a high percentage of fiscal decentralization were able to provide a better financial support and technical conditions for environment treatment (Tan Zhixiong and Zhang Yangyang, 2015) [4], which is contrary to the previous findings. It showed that the environment EKC curve did exist in China, but what was in a U-type relationship with environmental pollution investment might be the local finance capability rather than per capita GDP. Li Meng (2009) corrected the environmental Kuznets Hypothesis by including the fiscal decentralization into model, and demonstrated that the environmental pollution degree was in an inverted U-shaped relation with local finance capability through the empirical study [5]. From the perspective of the current academic community's definition of fiscal decentralization and index construction, the magnitude of fiscal decentralization mirrors the fiscal capacity and fiscal freedom of a place. This paper believes that when the degree of fiscal decentralization is low, the local government will reduce the environmental treatment investment due to the bias in the structure of fiscal expenditure, when the degree of fiscal decentralization is high, fiscal decentralization can provide a fund guarantee for environmental treatment investment. It is in a U-shaped relation with the amount of environmental treatment investment.

\section{Empirical Test}

\subsection{Model Setup}

This paper took the local government's environmental investment as a variable being explained and the degree of fiscal decentralization as an explanatory variable. The quadratic term of fiscal decentralization has been included into the model in order to test whether the fiscal decentralization is in a U-shaped relation with the environmental investment, and the first order lag term of environmental investment was introduced as an explanatory variable, the dynamic panel model has been used for estimation, the basic form of the model is as follows:

$$
\text { Inv }_{i t}=\beta_{0}+r E \operatorname{Inv}_{i t-1}+\beta_{1} \text { Fac }_{i t}+\beta_{2} \text { Fac }_{i t}^{2}+\beta_{3} \text { control }_{i t}+\varepsilon_{i t}
$$

where $E I n v_{i t}$ represents the amount of environmental investment of the $i$-th province in the tth year, EInv $v_{i t-1}$ is the first order lag term of $E I n v_{i t}, F a c_{i t}$ represents the degree of fiscal decentralization of the ith province in the $t$-th year, control ${ }_{i t}$ represents other control variables that affect the variable being explained, $\varepsilon_{i t}$ represents the stochastic error term.

\subsection{Selection of Variable and Sample}

In this paper, we select the provincial panel data of 1997-2013 in China as a sample, because this paper focuses on the impact of the fiscal decentralization between central government and province on the investment of environmental governance. The provincial panel data from 1997 to 2013 was used for empirical test in this paper, the Tibet region was culled, Chongqing was taken as a single cross-section sample. Before the estimation is made, it is necessary to explain the variable selection, data source and processing. In addition to the variable being explained and explanatory variable, the selection of control variable includes the economic development level, industrial structure, intensity of competition between governments, degree of opening to the outside world and population density.

As to the environmental investment of variable being explained, the amount of investment for treating the industrial wastewater, the amount of investment for treating the industrial waste gas and the amount of investment for treating the industrial solid wastes in various regions over the years were taken as variable being explained and a robustness test has been done to one another, to eliminate the endogenous effect of the economic development level, the ratio of amount of investment for treating the environment to GDP was taken as a variable being explained.

The budgetary fiscal expenditure at the provincial corresponding level/budgetary fiscal expenditure at the central corresponding level was taken as the degree of fiscal decentralization, the industrial added value in each 
province over the years was taken as the economic development level, the secondary industry-tertiary industry ratio was taken as the industrial structure, the proportion in national FDI accounted for by provincial FDI in that very year was taken as the intensity of competition between governments, the proportion in local GDP accounted for by total export-import volume was taken as the degree of opening to the outside world, the provincial area divided by the provincial permanent resident population at the end of a year was taken as the population density. The above data was mainly originated from China Statistical Yearbook, China Environment Yearbook, Almanac of China's Population, Finance Yearbook of China.

Before the regression is done, it is necessary to examine the distribution of each variable and its abnormal value. The feature of sample value of above-mentioned variables being explained, explanatory variables and control variables that have been established was described as follows (Table 1).

\subsection{Empirical Result}

By the use of above-mentioned model, the system generalized method of moment was used for estimation, the investment for treating the industrial waste gas/GDP, investment for treating the industrial waste water /GDP and investment for treating the industrial solid wastes /GDP were taken as variable being explained for robustness test, of which the regression result of two step method was as follows.

It can be seen from the regression result that (Table 2), the coefficients of variables of quadratic term of degree of fiscal decentralization were all positive, all the model coefficients were significant except for the one when the investment for treating the industrial solid wastes was taken as the variable being explained, indicating that, the estimating result was steady and dependable, in other words, the degree of fiscal decentralization was in a U-shaped relation with the environmental investment amount, the region having a low degree of fiscal decentralization will ignore the environmental problems due to financial budget constraint, while the region having a high degree of fiscal decentralization will provide a fund guarantee for environmental treatment, which is an extension of EKC curve. This conclusion was similar to that of Zhang Zhenyu and Zhu Pingfang (2010) [6], they believe that local environmental spending grows by fiscal accumulation on medium-low levers up to some higher threshold level where the spending starts to be fueled by strategic competition with neighboring municipalities.

\section{Conclusion and Suggestion}

This paper investigated the effect of fiscal decentralization on the environmental investment in China by the use of provincial panel data for empirical test; we believed that the degree of fiscal decentralization was in a Ushaped relation with environmental investment. The fiscal decentralization both had a substitution effect and an income effect on the environmental investment. When the fiscal capacity is weak, the substitution effect plays a leading role, fiscal decentralization will make the local governmental expenditure have a structural bias which

Table 1. The descriptive statistical table of variables.

\begin{tabular}{|c|c|c|c|c|c|}
\hline Variable & $\begin{array}{l}\text { Sample } \\
\text { number }\end{array}$ & $\begin{array}{l}\text { Mean } \\
\text { value }\end{array}$ & $\begin{array}{l}\text { Standard } \\
\text { deviation }\end{array}$ & $\begin{array}{l}\text { Minimum } \\
\text { value }\end{array}$ & $\begin{array}{l}\text { Maximum } \\
\text { value }\end{array}$ \\
\hline Aggregate investment for industrial treatment/GDP & 510 & 68.8070 & 55.9838 & 3.82914 & 454.758 \\
\hline Investment for treating the industrial waste gas /GDP & 510 & 34.3727 & 43.7886 & 0.280720 & 605.125 \\
\hline Investment for treating the industrial waste water /GDP & 510 & 23.9365 & 22.0773 & 0.502613 & 192.493 \\
\hline Investment for treating the industrial solid wastes /GDP & 510 & 3.98703 & 5.83558 & 0.002268 & 55.0776 \\
\hline Degree of fiscal decentralization & 510 & 0.111760 & 0.072878 & 0.01102 & 0.410858 \\
\hline Economic development level & 510 & 1055.32 & 1206.72 & 21.272 & 7391.60 \\
\hline Industrial structure & 510 & 1.2454 & 0.304921 & 0.289987 & 2.02276 \\
\hline Intensity of competition between governments & 510 & 0.033333 & 0.046797 & 0.000101 & 0.257553 \\
\hline Degree of opening to the outside world & 510 & 0.3106758 & 0.394605 & 0.032045 & 1.72148 \\
\hline Population density & 510 & 407.8525 & 559.534 & 7.11047 & 3808.85 \\
\hline
\end{tabular}


Table 2. The effect of fiscal decentralization on the environmental investment.

\begin{tabular}{|c|c|c|c|c|}
\hline \multirow[b]{2}{*}{ Explanatory variable } & \multicolumn{4}{|c|}{ (SYS-GMM two step method) } \\
\hline & $\begin{array}{l}\text { Aggregate investment } \\
\text { for industrial } \\
\text { treatment/GDP }\end{array}$ & $\begin{array}{l}\text { The investment for } \\
\text { treating the industrial } \\
\text { waste gas/GDP }\end{array}$ & $\begin{array}{l}\text { Investment for } \\
\text { treating the industrial } \\
\text { waste water/GDP }\end{array}$ & $\begin{array}{l}\text { Investment for } \\
\text { treating the industrial } \\
\text { solid wastes/GDP }\end{array}$ \\
\hline \multirow{2}{*}{$\begin{array}{l}\text { The first order lag of each } \\
\text { variable being explained }\end{array}$} & $0.244^{* * *}$ & $0.166^{* * *}$ & $0.259^{* * *}$ & $0.0500^{* * *}$ \\
\hline & $(0.0540)$ & $(0.0308)$ & $(0.0414)$ & $(0.0185)$ \\
\hline \multirow{2}{*}{$\begin{array}{l}\text { Degree of fiscal } \\
\text { decentralization }\end{array}$} & $-655.9^{* * * *}$ & $-441.2^{* * *}$ & $-316.6^{* * *}$ & 22.90 \\
\hline & $(80.72)$ & $(68.43)$ & $(67.12)$ & $(31.90)$ \\
\hline \multirow{2}{*}{$\begin{array}{l}\text { The quadratic term of } \\
\text { degree of fiscal decentralization }\end{array}$} & $586.4^{* *}$ & $335.9^{*}$ & $650.4^{* * *}$ & 0.300 \\
\hline & $(232.8)$ & $(177.4)$ & $(235.9)$ & $(104.7)$ \\
\hline \multirow{2}{*}{$\begin{array}{l}\text { Economic development level } \\
\text { (taking the logarithm) }\end{array}$} & $22.16^{* * *}$ & $20.68^{* * *}$ & 1.027 & $-1.600^{* * *}$ \\
\hline & (5.986) & $(6.217)$ & $(2.373)$ & $(0.522)$ \\
\hline \multirow{2}{*}{ Industrial structure } & 12.41 & $-19.17^{* * *}$ & $20.93^{* * *}$ & $-2.572^{*}$ \\
\hline & $(23.01)$ & $(5.724)$ & $(2.343)$ & $(1.521)$ \\
\hline \multirow{2}{*}{$\begin{array}{l}\text { Intensity of competition } \\
\text { between governments }\end{array}$} & $-152.3^{*}$ & -207.9 & -89.25 & -7.818 \\
\hline & $(377.0)$ & $(343.2)$ & $(100.3)$ & $(34.75)$ \\
\hline \multirow{2}{*}{$\begin{array}{l}\text { Degree of opening } \\
\text { to the outside world }\end{array}$} & $46.29^{*}$ & -23.28 & 5.371 & $3.584^{* *}$ \\
\hline & (24.65) & (21.69) & (5.513) & $(1.517)$ \\
\hline \multirow{2}{*}{ Population density } & -19.35 & $-10.98^{* * *}$ & -5.925 & $-3.093^{* * *}$ \\
\hline & $(14.52)$ & (3.183) & (4.539) & $(0.337)$ \\
\hline \multirow{2}{*}{ Constant term } & 47.87 & 34.18 & 41.51 & $30.58^{* * *}$ \\
\hline & (88.58) & $(25.57)$ & (28.37) & (2.564) \\
\hline $\begin{array}{l}\text { Over-distinguished } \\
\text { P value (Sargan test ) }\end{array}$ & 1 & 1 & 1 & 1 \\
\hline $\begin{array}{l}\text { Second order serial } \\
\text { correlation testing } \mathrm{P} \text { value }\end{array}$ & 0.1512 & 0.5532 & 0.3299 & 0.2710 \\
\hline Sample number & 480 & 480 & 480 & 480 \\
\hline
\end{tabular}

Note: ${ }^{*},{ }^{* *},{ }^{* * *}$ respectively represent being significant at the level of $10 \%, 5 \%, 1 \%$.

in turn will inhibit the environmental investment; when the fiscal capacity is strong, the income effect plays a leading role, fiscal decentralization can provide a fund support for environmental investment. Thus, a fiscal system reform has to be sped up, and the transfer payment from the exchequer to the less developed areas needs to be enhanced to enable the fiscal decentralization system in the less developed areas to exert an "income effect".

\section{References}

[1] Zhang, X.Y. (2015) Study on the local Governmental Behavior and Environment Pollution Issue with the Background of Fiscal Decentralization. Inquiry into Economic Issues, No. 3, 32-41.

[2] Fu, Y. (2010) Fiscal Decentralization, Government Treatment and Supply of Non-Economic Public Goods. Economic Research, No. 8, 4-15.

[3] Yang, R.L., Zhang, Q. and Zhou, Y.A. (2007) fiscal Decentralization, Public Preference and Environment Pollution-The Evidence from Chinese Provincial Panel Data. Macroeconomic Report of Institute of Economics of School of Economics of Renmin University of China, Beijing.

[4] Li, M. (2009) Fiscal Decentralization and Environment Pollution—Correction to Environmental Kuznets Assumption. 
Economic Review, No. 5, 54-59.

[5] Tan, Z.X. and Zhang, Y.Y. (2015) Empirical Study on the Relation between Fiscal Decentralization and Environment Pollution. China Population Resources and Environment, No. 4, 110-117.

[6] Zhang, Y.Z. and Zhu, P.F. (2010) Empirical Study on the Local Environmental Expenditure. Economic research, No. 5, 82-93. 